\title{
Attuned Learning
}

Rabbinic Texts on Habits of the Heart in Learning Interactions 
Jewish Identity in Post-Modern Society

\section{Series Editor}

Roberta ROSENBERG FARBER (Yeshiva University, New York)

\section{Editorial Board}

Sara ABOSCH (University of Memphis, Memphis, Tennessee)

Geoffrey ALDERMAN (University of Buckingham, Buckingham)

Yoram BILU (Hebrew University, Jerusalem)

Steven M. COHEN (Hebrew Union College, New York)

Deborah DASH MOORE (University of Michigan, Ann Arbor)

Bryan DAVES (Yeshiva University, New York)

Sergio DELLA PERGOLA (Hebrew University, Jerusalem)

Simcha FISHBANE (Touro College, New York)

Uzi REBHUN (Hebrew University, Jerusalem)

Reeva SIMON (Yeshiva University, New York)

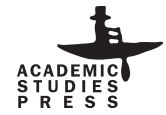




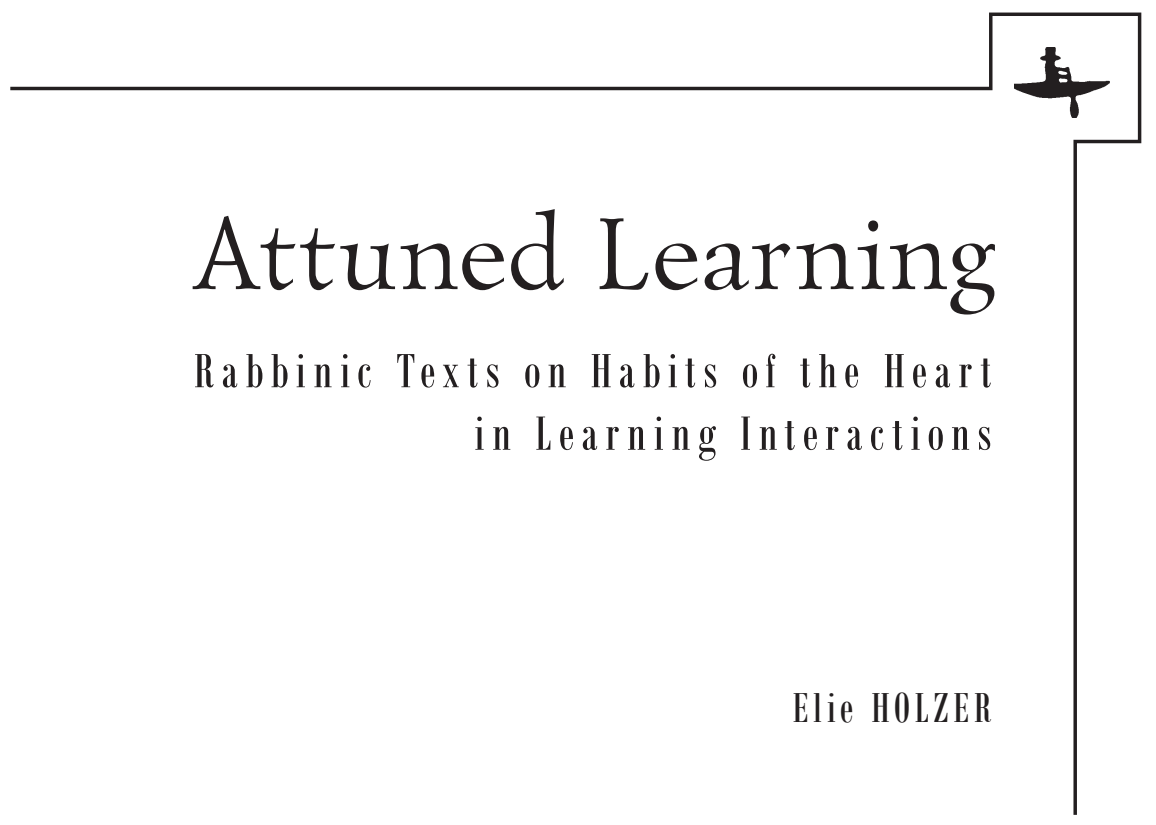

BOSTON / 2016 
Library of Congress Cataloging-in-Publication Data: A bibliographic record for this title is available from the Library of Congress.

Copyright ( 2016 Academic Studies Press All rights reserved.

ISBN 978-1-61811-480-8 (cloth) ISBN 978-1-61811-481-5 (electronic)

Cover design by Ivan Grave

Published by Academic Studies Press in 2016 28 Montfern Avenue Brighton, MA 02135, USA press@academicstudiespress.com www.academicstudiespress.com 
To Suzi, Lital, Vered, Avigail, and Noam For being the bliss of my earthly existence 
There is an initiative trust, an investment of belief, underwritten by previous experience but epistemologically exposed and psychologically hazardous, in the meaningfulness, in the "seriousness" of the facing or, strictly speaking, adverse text. We venture a leap: we grant $a b$ initio that there is "something there" to be understood [...] All understanding [. . .] starts with an act of trust. This confiding will, ordinarily, be instantaneous and unexamined, but it has a complex base. It is an operative convention which derives from a sequence of phenomenological assumptions about the coherence of the world, about the presence of meaning in very different, perhaps formally antithetical semantic systems, about the validity of analogy and parallel.

-George Steiner, After Babel:

Aspects of Language and Translation, 312

To quote is to reflect on what has been said before, and unless we do that, we speak in a vacuum where no human voice can make a sound.

- Alberto Manguel, The Library at Night, 224

The search for references to universality in the Scriptures and in the texts of the spoken Law still derives from the process of assimilation. These texts, across two thousand years of commentary, still have something other to say.

-Emmanuel Levinas, Assimilation and New Culture, 287 